\title{
Evaluating the impact of maternal vitamin D supplementation on sow performance: II. Subsequent growth performance and carcass characteristics of growing pigs ${ }^{1,2}$
}

\author{
J. R. Flohr,*3 J. C. Woodworth,* J. R. Bergstrom, $†$ \\ M. D. Tokach, * S. S. Dritz, \$ R. D. Goodband, $* 4$ and J. M. DeRouchey* \\ *Department of Animal Sciences and Industry, College of Agriculture, Kansas State \\ University, Manhattan 66506-020; †DSM Nutritional Products, Parsippany, NJ 07054; and \$Department \\ of Diagnostic Medicine/Pathobiology, College of Veterinary Medicine, Kansas State University, Manhattan 66506-020
}

\begin{abstract}
A of subsample of 448 growing pigs $($ PIC $327 \times 1050)$ weaned from 52 sows fed varying dietary vitamin $\mathrm{D}$ regimens were used in a split-plot design to determine the effects of maternal and nursery dietary vitamin D on growth performance. Sows were previously administered diets containing vitamin $\mathrm{D}$ as vitamin $\mathrm{D}_{3}(800,2,000$, or $9,600 \mathrm{IU} / \mathrm{kg})$ or as $25(\mathrm{OH}) \mathrm{D}_{3}(50 \mu \mathrm{g}$ [or 2,000 IU vitamin D equivalent]/ kg from HyD; DSM Nutritional Products, Parsippany, NJ). Once weaned, pigs were allotted to pens on the basis of previous maternal vitamin D treatment, and then pens were randomly assigned to 1 of 2 nursery vitamin D dietary regimens $\left(2,000 \mathrm{IU}\right.$ of vitamin $\mathrm{D}_{3} /$ $\mathrm{kg}$ or $\left.50 \mu \mathrm{g} 25(\mathrm{OH}) \mathrm{D}_{3} / \mathrm{kg}\right)$. Pigs remained on nursery vitamin $\mathrm{D}$ treatments for $35 \mathrm{~d}$, and then they were provided common finishing diets until market $(135 \mathrm{~kg})$. Growing pig serum $25(\mathrm{OH}) \mathrm{D}_{3}$ suggested that maternal dietary vitamin $\mathrm{D}$ influenced $(P<0.001$ at weaning) serum concentrations early after weaning, but nursery vitamin $\mathrm{D}$ regimen had a larger impact $(P<0.001)$ on $\mathrm{d} 17$ and 35 postweaning. Overall growth performance was not influenced by nursery vitamin D dietary treatments. From $\mathrm{d} 0$ to 35 in the nursery, pigs from sows fed increasing vitamin $\mathrm{D}_{3}$ had increased (quadratic, $P<0.003$ ) ADG and ADFI, but
\end{abstract}

G:F was similar regardless of maternal vitamin D regimen. Also, pigs from sows fed $50 \mu \mathrm{g} / \mathrm{kg}$ of $25(\mathrm{OH})$ $\mathrm{D}_{3}$ had increased $(P=0.002)$ ADG compared with pigs weaned from sows fed $800 \mathrm{IU}$ of vitamin $\mathrm{D}_{3}$. Throughout finishing (d 35 postweaning until $135 \mathrm{~kg}$ ), ADG was increased (quadratic, $P=0.005$ ) and $\mathrm{G}: \mathrm{F}$ was improved (quadratic, $P=0.049$ ) with increasing maternal dietary vitamin $\mathrm{D}_{3}$. Also, pigs from sows fed $50 \mu \mathrm{g} / \mathrm{kg}$ of $25(\mathrm{OH}) \mathrm{D}_{3}$ had increased $(P=0.002)$ ADG compared with pigs weaned from sows fed 800 IU of vitamin $\mathrm{D}_{3}$. Carcass data were collected from a subsample population separate from that used for the growth performance portion of the study, and a total of 642 carcasses from progeny of sows fed the varying dietary vitamin $\mathrm{D}$ treatments were used. Live BW of pigs at marketing and $\mathrm{HCW}$ were heavier $(P<0.030)$ for pigs from sows previously fed $25(\mathrm{OH}) \mathrm{D}_{3}$ compared with pigs from sows fed $9,600 \mathrm{IU}$ of vitamin $\mathrm{D}_{3}$. Overall, pigs from sows fed 2,000 IU of vitamin $\mathrm{D}_{3}$ grew faster after weaning compared with pigs from sows fed 800 or $9,600 \mathrm{IU}$ of vitamin $\mathrm{D}_{3}$. Pigs from sows fed $25(\mathrm{OH}) \mathrm{D}_{3}$ hag greater ADG compared with pigs from sows fed $800 \mathrm{IU}$ of vitamin $\mathrm{D}_{3}$, and they had increased final BW and HCW compared with pigs from sows fed 9,600 IU of vitamin $\mathrm{D}_{3}$.

Key words: $25(\mathrm{OH}) \mathrm{D}_{3}$, finishing pig, growth, nursery pig, vitamin $\mathrm{D}$

(C) 2016 American Society of Animal Science. All rights reserved.

\footnotetext{
${ }^{1}$ Contribution number 16-228-J from the Kansas Agricultural Experiment Station, Manhattan, KS.

${ }^{2}$ The authors with to thank DSM Nutritional Products, Parsippany, $\mathrm{NJ}$, for partial financial support.

${ }^{3}$ Present address: Nutriquest, Mason City, IA 50401.

${ }^{4}$ Corresponding author: goodband@ksu.edu

Received February 23, 2016.

Accepted August 20, 2016.
}

J. Anim. Sci. 2016.94:4643-4653 doi:10.2527/jas2016-0410

\section{INTRODUCTION}

Studies evaluating maternal dietary manipulation have determined that fetal muscle development in swine can be altered on the basis of nutritional strategies (Dwyer et al., 1994; Musser et al., 2004). Dwyer et al. (1993) concluded that differences in the total number of muscle fibers at birth, resulting from 
fetal muscle development, were positively correlated with postnatal growth potential. Additionally, previous research in mice has demonstrated that vitamin D plays a role in fetal muscle development. Endo et al. (2003) concluded that skeletal muscle in knockout mice without the vitamin D receptor (VDR) gene had approximately $20 \%$ smaller muscle fiber diameters at 3 wk of age compared to wild-type mice.

Hines et al. (2013) evaluated feeding $25(\mathrm{OH}) \mathrm{D}_{3}$ or vitamin $\mathrm{D}_{3}$ to bred gilts and observed alterations in fetal muscle characteristics for fetuses from gilts fed the $25(\mathrm{OH}) \mathrm{D}_{3}$ compared to fetuses from gilts fed vitamin $\mathrm{D}_{3}$ when fed at concentrations above the basal requirement estimate (NRC, 2012). There was an increase in the number of muscle fibers and an increase in the number of Pax7 (satellite cells) + myoblasts within the LM. These alterations would suggest the potential for increased postnatal growth performance. Weber et al. (2014) observed increases in piglet $\mathrm{BW}$ at birth and weaning in piglets from dams supplemented $50 \mu \mathrm{g}$ of $25(\mathrm{OH}) \mathrm{D}_{3} / \mathrm{kg}$ compared with piglets from dams supplemented 2,000 $\mathrm{IU}$ of vitamin $\mathrm{D}_{3} / \mathrm{kg}$. However, no previous research has evaluated whether pigs from dams supplemented varying forms or concentrations of vitamin D have improved postnatal growth after weaning or the impacts of maternal vitamin $\mathrm{D}$ on carcass characteristics.

Therefore, the objectives of the experiments herein were 1) to determine the vitamin D status of pigs within a subsample population from dams fed varying vitamin D regimens and 2) to evaluate the influence of maternal vitamin $\mathrm{D}$ status and nursery dietary vitamin $\mathrm{D}$ regimen on growth performance and carcass characteristics.

\section{MATERIALS AND METHODS}

Experimental procedures and animal care were approved by the Kansas State University Institutional Animal Care and Use Committee. These experiments were conducted at the K-State Swine Teaching and Research Facility in Manhattan, KS, from September of 2014 to May of 2015. Nursery and finishing diets were prepared at the Kansas State University O. H. Kruse Feed Mill (Manhattan, KS). All diets were formulated to meet or exceed nutrient requirement estimates (NRC, 2012). The pigs used in this study were derived from sows fed different concentrations and sources of vitamin $\mathrm{D}$ as described in a companion paper (Flohr et al., 2016).

All nursery and finishing facilities were totally enclosed, environmentally controlled, and mechanically ventilated buildings. Pigs in the first weaning group were housed in nursery pens that were $1.22 \times 1.52 \mathrm{~m}$ with a 4-hole dry self-feeder and a single nipple waterer to provide ad libitum access to feed and water. Pens had wire mesh flooring and allowed $0.28 \mathrm{~m}^{2} /$ pig. On d 55 af- ter weaning, pigs were moved to the finishing barn into pens that were $1.52 \times 3.05 \mathrm{~m}$ with totally slatted concrete flooring (providing $0.77 \mathrm{~m} 2$ space/pig). Each pen was equipped with a 2-hole dry self-feeder and 2 nipple waterers to provide ad libitum access to feed and water. Pigs in the second weaning group were housed in nursery pens that were $1.52 \times 1.52 \mathrm{~m}$ with tri-bar flooring (providing $0.60 \mathrm{~m} 2$ space/pig). Each pen was equipped with a 3-hole dry self-feeder and a nipple waterer to allow for ad libitum access to feed and water. These pigs were moved to the finishing pens $(2.44 \times 3.05 \mathrm{~m})$ with totally slatted flooring (providing $0.93 \mathrm{~m} 2$ space/pig). Each pen was equipped with a 2-hole dry self-feeder and bowl waterer to allow ad libitum access to feed and water. Feed was delivered to each pen individually by a robotic feeding system (FeedPro; Feedlogic Corp., Wilmar, MN).

In total 448 pigs (PIC $327 \times 1050$, Hendersonville, $\mathrm{TN})$ from 52 litters from 2 consecutive weaned pig groups (approximately 50\% of pigs weaned from the maternal trial discussed by Flohr et al., 2016) were used as a subsample of the weaned pig population in a $4 \times$ 2 split-plot design to determine the effects of maternal vitamin $\mathrm{D}$ treatment and nursery dietary vitamin $\mathrm{D}$ regimen on growth performance. Sows were previously administered 1 of 4 maternal dietary vitamin $\mathrm{D}$ treatments, receiving either vitamin $\mathrm{D}_{3}(800,2,000$, or $9,600 \mathrm{IU} / \mathrm{kg}$ of diet) or $25(\mathrm{OH}) \mathrm{D}_{3}(50 \mu \mathrm{g}$ [2,000 IU vitamin D equivalent $] / \mathrm{kg}$ of diet; Hy-D, DSM Nutritional Products North America, Parsippany, NJ) throughout gestation and lactation as discussed by Flohr et al. (2016). Prior to weaning, all pigs were weighed to determine the average weaning weight and SD of weaning weight among maternal treatments. Because all pigs were not used, a subsample of litters was selected to represent the mean and variance among maternal treatments differences at weaning within each of the 2 weaning groups used in the study. At weaning, pigs were allotted to pens on the basis of their previously administered maternal vitamin D regimen. Pens were then randomly assigned to the nursery regimen of feeding diets containing either 2,000 IU vitamin $\mathrm{D}_{3}$ or $50 \mu \mathrm{g} 25(\mathrm{OH}) \mathrm{D}_{3} / \mathrm{kg}$. There were 7 pigs per pen and 4 pens per treatment in the first wean group and 4 pigs per pen and 8 or 9 pens per treatment in the second wean group. Dietary vitamin D regimens remained consistent in 3 consecutive nursery diets that were fed from $\mathrm{d} 0$ to $10, \mathrm{~d} 10$ to 21 , and $\mathrm{d} 21$ to 35 for phases 1,2 , and 3 , respectively. The nursery diets were formulated to contain $1.40 \%, 1.34 \%$, and $1.22 \%$ standardized ileal digestible (SID) lysine (Table 1) for phases 1, 2, and 3, respectively. Phase 1 nursery diets were pelleted, and all other diets were in meal form. Pigs and feeders were weighed on d $0,10,21$, and 35 to determine ADG, ADFI, and G:F.

After d 35 postweaning, pigs were switched to a common growing pig diet (phase 4) and then were 
Table 1. Nursery and finishing diet composition (as-fed basis) ${ }^{1}$

\begin{tabular}{|c|c|c|c|c|c|c|}
\hline \multirow[b]{2}{*}{ Item } & \multicolumn{3}{|c|}{ Nursery diets ${ }^{2}$} & \multicolumn{3}{|c|}{ Finishing diets ${ }^{3}$} \\
\hline & Phase 1 & Phase 2 & Phase 3 & Phase 4 & Phase 5 & Phase 6 \\
\hline \multicolumn{7}{|l|}{ Ingredient, \% } \\
\hline Corn & 35.68 & 46.01 & 56.39 & 71.50 & 78.44 & 82.86 \\
\hline Soybean meal, $46.5 \% \mathrm{CP}$ & 22.09 & 20.37 & 24.27 & 25.71 & 19.20 & 14.93 \\
\hline Corn DDGS ${ }^{4}$ & 5.00 & 15.00 & 15.00 & - & - & - \\
\hline Fish meal & 5.00 & 5.00 & - & - & - & - \\
\hline Spray-dried whey & 25.00 & 10.00 & - & - & - & - \\
\hline Choice white grease & 3.00 & - & - & - & - & - \\
\hline Monocalcium phosphate, $21.5 \% \mathrm{P}$ & 0.15 & 0.23 & 0.88 & 0.55 & 0.33 & 0.30 \\
\hline Calcium carbonate & 1.05 & 1.13 & 1.35 & 1.13 & 1.10 & 1.08 \\
\hline Sodium chloride & 0.30 & 0.30 & 0.35 & 0.35 & 0.35 & 0.35 \\
\hline L-Lys $\mathrm{HCl}$ & 0.40 & 0.45 & 0.50 & 0.31 & 0.25 & 0.22 \\
\hline DL-Met & 0.20 & 0.14 & 0.13 & 0.06 & 0.02 & - \\
\hline L-Thr & 0.17 & 0.16 & 0.17 & 0.09 & 0.05 & 0.05 \\
\hline L-Trp & 0.04 & 0.05 & 0.04 & - & - & - \\
\hline L-Val & 0.09 & 0.03 & 0.03 & - & - & - \\
\hline Choline chloride, $60 \%$ & 0.04 & - & - & - & - & 一 \\
\hline Zinc oxide & 0.39 & 0.25 & - & - & - & - \\
\hline Medication $^{5}$ & 1.00 & 0.50 & 0.50 & - & - & - \\
\hline Phytase $^{6}$ & 0.02 & 0.02 & 0.02 & 0.02 & 0.02 & 0.02 \\
\hline Trace mineral premix ${ }^{7}$ & 0.15 & 0.15 & 0.15 & 0.15 & 0.13 & 0.10 \\
\hline Vitamin premix 8 & 0.25 & 0.25 & 0.25 & 0.15 & 0.13 & 0.10 \\
\hline Total & 100.00 & 100.00 & 100.00 & 100.00 & 100.00 & 100.00 \\
\hline \multicolumn{7}{|l|}{ Calculated analysis } \\
\hline \multicolumn{7}{|l|}{$\operatorname{SID~AA},{ }^{9} \%$} \\
\hline Lys & 1.40 & 1.34 & 1.22 & 1.05 & 0.85 & 0.72 \\
\hline Met and Cys:Lys & 57 & 57 & 57 & 55 & 56 & 59 \\
\hline Thr:Lys & 63 & 63 & 63 & 61 & 61 & 64 \\
\hline Trp:Lys & 19 & 19 & 19 & 18 & 18 & 18 \\
\hline Val:Lys & 68 & 68 & 68 & 69 & 73 & 76 \\
\hline $\mathrm{NE}, \mathrm{Mcal} / \mathrm{kg}$ & 2.58 & 2.43 & 2.40 & 2.47 & 2.51 & 2.54 \\
\hline SID Lys:NE, g/Mcal & 5.43 & 5.51 & 5.08 & 4.25 & 3.39 & 2.83 \\
\hline $\mathrm{CP}, \%$ & 21.6 & 22.6 & 21.0 & 18.5 & 15.9 & 14.2 \\
\hline $\mathrm{Ca}, \%$ & 0.86 & 0.81 & 0.74 & 0.62 & 0.55 & 0.52 \\
\hline $\mathrm{P}, \%$ & 0.63 & 0.62 & 0.60 & 0.49 & 0.41 & 0.39 \\
\hline Available P, \% & 0.51 & 0.47 & 0.42 & 0.29 & 0.23 & 0.22 \\
\hline STTD P, \% & 0.43 & 0.41 & 0.36 & 0.34 & 0.28 & 0.27 \\
\hline Ca:P & 1.36 & 1.30 & 1.23 & 1.28 & 1.34 & 1.35 \\
\hline
\end{tabular}

${ }^{1}$ A total of 448 pigs from 52 litters in 2 farrowing groups were used in a 35-d nursery trial. There were a total of 7 pigs per pen and 4 pens per treatment in the first weaning group, and there were 4 pigs per pen and either 8 or 9 pens per treatment in the second weaning group.

${ }^{2}$ Phase 1 diets were fed from d 0 (weaning) until d 10, phase 2 diets were fed from d 10 to 21, and phase 3 diets were fed from d 21 to 35 . Experimental treatments were made by adding either a vitamin $\mathrm{D}_{3}$ premix $\left(4,409,240 \mathrm{IU} / \mathrm{kg}\right.$ of premix) in the diet replacing corn or $0.33 \mathrm{~kg} / \mathrm{t}$ of $25(\mathrm{OH}) \mathrm{D}_{3}(\mathrm{Hy}-\mathrm{D}$; $\mathrm{DSM}$ Nutritional Products North America, Parsippany, NJ) replacing corn.

${ }^{3}$ Common finishing diets were fed from approximately 23 to $55 \mathrm{~kg}, 55$ to $93 \mathrm{~kg}$, and $93 \mathrm{~kg}$ until market for phases 4, 5, and 6, respectively. Common finishing diets were formulated to contain 827,690 , and $551 \mathrm{IU}$ of vitamin $\mathrm{D}_{3}$ per kg of complete diet for phases 4,5 , and 6 , respectively.

${ }^{4}$ Dried distillers grains with solubles.

${ }^{5}$ Mecadox 2.5 (Phibro Animal Health, Ridgefiled Park, NJ). Provided $44 \mathrm{mg} / \mathrm{kg}$ of carbadox in phase 1 nursery diets and $22 \mathrm{mg} / \mathrm{kg}$ of carbadox in phase 2 and 3 diets.

${ }^{6}$ Ronozyme Hi-Phos (DSM Nutritional Products North America). Provided 476 phytase units (FTU/kg) of diet with an expected release of $0.10 \%$ phytate P.

${ }^{7}$ Provided 11,000 mg/kg Cu, $198 \mathrm{mg} / \mathrm{kg} \mathrm{I}, 73,413 \mathrm{mg} / \mathrm{kg} \mathrm{Fe}, 22,046 \mathrm{mg} / \mathrm{kg} \mathrm{Mn}, 198 \mathrm{mg} / \mathrm{kg} \mathrm{Se}$, and 74,413 mg/kg Zn per kilogram of premix.

${ }^{8}$ Provided 3,527,392 IU vitamin A, 17,637 IU vitamin E, 1,764 mg vitamin K, $15 \mathrm{mg}$ vitamin $\mathrm{B}_{12}, 33,069 \mathrm{mg}$ niacin, 11,023 mg pantothenic acid, and $3,307 \mathrm{mg}$ riboflavin per kilogram of premix.

${ }^{9} \mathrm{SID}=$ standardized ileal digestible. 
transported to the finishing facility approximately 55 $\mathrm{d}$ after weaning. Pigs remained penned by maternal and dietary nursery treatments in the finisher; however, because the pen sizes changed from the nursery to the finisher, pigs were remixed within treatments and were randomly allotted to finishing pens. In finishing, all pigs received common diets formulated to contain 827,690 , and $551 \mathrm{IU}$ of vitamin $\mathrm{D}_{3} / \mathrm{kg}$ for phases 4,5 , and 6 , respectively. Pigs were weighed, and feed disappearance was calculated every $28 \mathrm{~d}$ until marketing $(135 \mathrm{~kg})$.

\section{Feed Preparation and Vitamin D Analysis}

To achieve the dietary vitamin $\mathrm{D}_{3}$ concentrations, a premix was made containing a vitamin $\mathrm{D}_{3}$ supplement (Rovimix $\mathrm{D}_{3}, 500,000 \mathrm{IU} / \mathrm{g}$; DSM Nutritional Products North America). This supplement was mixed with a rice hull carrier to form the premix and was added to the control diet by replacing corn. The vitamin D premix was the only source of added vitamin D within the diets, as other vitamin premixes did not contain vitamin D. For diets formulated to contain $50 \mu \mathrm{g}$ of $25(\mathrm{OH}) \mathrm{D}_{3} / \mathrm{kg}$, $390 \mathrm{~g}$ of $25(\mathrm{OH}) \mathrm{D}_{3}$ (Hy-D, DSM Nutritional Products North America; $125 \mu \mathrm{g} / \mathrm{g}$ ) were added per ton of the diet to provide $50 \mu \mathrm{g}$ of $25(\mathrm{OH}) \mathrm{D}_{3} / \mathrm{kg}$. Complete nursery diet samples were analyzed for vitamin $\mathrm{D}_{3}$ and $25(\mathrm{OH})$ $\mathrm{D}_{3}$ concentrations by DSM Nutritional Products using a combination HPLC and mass spectrometry analytical technique (Schadt et al., 2012).

\section{Serum 25-Hydroxycholecalciferol, Vitamin $D_{3}$, a-Tocopherol, and Retinol}

One pig per pen (randomly selected) was bled via jugular venipuncture at weaning (d 21) and d 17, 35, and 70 postweaning to determine serum vitamin metabolites. All blood samples were collected via jugular venipuncture using 25-mm 20-gauge needles and 10$\mathrm{mL}$ blood collection tubes containing a gel separator. Six hours after collection, blood was centrifuged (1,600 $\times g$ for $25 \mathrm{~min}$ at $2^{\circ} \mathrm{C}$ ), and serum was harvested and stored at $-20^{\circ} \mathrm{C}$ until analysis. All vitamin metabolite testing $\left(25(\mathrm{OH}) \mathrm{D}_{3}\right.$, vitamin $\mathrm{D}_{3}, \alpha$-tocopherol, and retinol) was conducted by DSM Nutritional Product's laboratory (Kaiseraugst, Switzerland). The analyses were performed using a liquid chromatography/electrospray ionization tandem mass spectrometry technique with multiple reaction monitoring similar to the methods described by Priego Capote et al. (2007). The lowest detectable limit for $25(\mathrm{OH}) \mathrm{D}_{3}$ was $5.00 \mathrm{ng} / \mathrm{mL}$; for vitamin $\mathrm{D}_{3}$ it was $1.00 \mathrm{ng} / \mathrm{mL}$, for $\alpha$-tocopherol it was $250 \mathrm{ng} / \mathrm{mL}$, and for retinol it was $25 \mathrm{ng} / \mathrm{mL}$. Over half of the serum samples were below the detectable limit for serum vitamin $\mathrm{D}_{3}$ concentration $(n=130$ out of 256 total samples); therefore, the percentage of animals with serum concentrations above the detectable limit is reported herein along with the mean concentration of serum vitamin $\mathrm{D}_{3}$ associated with those animals.

\section{Carcass Characteristics}

Carcass data were collected from 642 pigs, or approximately $75 \%$ ( 3 of the 4 weaned pig groups), of the weaned progeny from the maternal portion of the study (Flohr et al., 201). Pigs were individually weighed and tattooed for slaughter at a commercial abattoir (Triumph Foods, St. Joseph, MO). Hot carcass weights were measured immediately after evisceration, and each carcass was evaluated for percentage carcass yield, back fat, and loin depth. Percentage carcass yield was calculated by dividing HCW by live weight obtained at the farm before transport to the abattoir. Fat depth and loin depth were measured with an optical probe (SFK, Herlev, Denmark) inserted between the third and fourth ribs located anterior to the last rib at a distance approximately $7 \mathrm{~cm}$ from the dorsal midline.

\section{Statistical Analysis}

All growth data were analyzed as a split-plot design using the GLIMMIX procedure of SAS (SAS Inst. Inc., Cary, NC). Maternal vitamin D regimen acted as the whole-plot unit, and nursery vitamin $\mathrm{D}$ regimen acted as the split-plot unit. Pen was the experimental unit, and weaning group was included in the model as a random effect. Contrast statements tested for maternal vitamin D treatments included 1) increasing maternal vitamin $\mathrm{D}_{3}$ linear and quadratic polynomials and 2) $800 \mathrm{IU}$ vitamin $\mathrm{D}_{3}$ vs. $\left.50 \mu \mathrm{g} 25(\mathrm{OH}) \mathrm{D}_{3}, 3\right) 2,000 \mathrm{IU}$ vitamin $\mathrm{D}_{3}$ vs. $50 \mu \mathrm{g} 25(\mathrm{OH}) \mathrm{D}_{3}$, and 4) $9,600 \mathrm{IU}$ vitamin $\mathrm{D}_{3}$ vs. 50 $\mu \mathrm{g} 25(\mathrm{OH}) \mathrm{D}_{3}$. The IML procedure of SAS was used to generate unequally spaced contrast coefficients for maternal dietary vitamin $\mathrm{D}_{3}$ treatments. Because of unbalanced sample sizes for maternal treatments, a TukeyKramer multiple comparison adjustment was used for the maternal vitamin D pairwise comparison tests. Repeated measures analysis was performed on the serum vitamin metabolite responses, and day of collection was included as a fixed effect to determine serum changes to dietary treatments over time. For carcass data, maternal vitamin $\mathrm{D}$ treatment served as the fixed effect, and weaning group acted as a random effect in the model. The percentage carcass yield was analyzed using a $\beta$ distribution. Results were considered significant at $P \leq 0.05$ and a tendency at $P \leq 0.10$. 
Table 2. Analyzed nursery diet composition (as-fed basis) ${ }^{1}$

\begin{tabular}{|c|c|c|c|c|c|c|}
\hline \multirow[b]{3}{*}{ Item } & \multicolumn{6}{|c|}{ Nursery diets } \\
\hline & \multicolumn{2}{|c|}{ Phase 1} & \multicolumn{2}{|c|}{ Phase 2} & \multicolumn{2}{|c|}{ Phase 3} \\
\hline & $\mathrm{D}_{3}$ & $25(\mathrm{OH}) \mathrm{D}_{3}$ & $\mathrm{D}_{3}$ & $25(\mathrm{OH}) \mathrm{D}_{3}$ & $\mathrm{D}_{3}$ & $25(\mathrm{OH}) \mathrm{D}_{3}$ \\
\hline \multicolumn{7}{|l|}{ Formulated } \\
\hline $\mathrm{CP}, \%$ & 21.6 & 21.6 & 22.6 & 22.6 & 21 & 21 \\
\hline $\mathrm{Ca}, \%$ & 0.86 & 0.86 & 0.81 & 0.81 & 0.74 & 0.74 \\
\hline $\mathrm{P}, \%$ & 0.63 & 0.63 & 0.62 & 0.62 & 0.60 & 0.60 \\
\hline Vitamin $\mathrm{D}_{3}, \mathrm{IU} / \mathrm{kg}$ & 2,000 & - & 2,000 & - & 2,000 & - \\
\hline $25(\mathrm{OH}) \mathrm{D}_{3}, \mathrm{IU} / \mathrm{kg}$ & - & 2,000 & - & 2,000 & - & 2,000 \\
\hline \multicolumn{7}{|l|}{ Analyzed $^{2}$} \\
\hline $\mathrm{CP}, \%$ & 21.8 & 22.4 & 24.2 & 23.2 & 23.1 & 22.4 \\
\hline $\mathrm{Ca}, \%$ & 1.04 & 1.04 & 1.03 & 1.02 & 0.80 & 0.9 \\
\hline $\mathrm{P}, \%$ & 0.65 & 0.64 & 0.71 & 0.70 & 0.61 & 0.61 \\
\hline Vitamin $\mathrm{D}_{3}, \mathrm{IU} / \mathrm{kg}$ & 2,240 & - & 1,700 & - & 2,110 & - \\
\hline $25(\mathrm{OH}) \mathrm{D}_{3}, \mathrm{IU} / \mathrm{kg}$ & - & 1,580 & - & 1,500 & - & 1,540 \\
\hline Percentage of formulated & 112 & 79 & 85 & 75 & 106 & 77 \\
\hline
\end{tabular}

${ }^{1}$ Means represent the average of 2 pooled samples.

${ }^{2}$ Crude protein, Ca, and P were determined at Ward laboratories (Kearney, NE). Vitamin $\mathrm{D}_{3}$ and $25(\mathrm{OH}) \mathrm{D}_{3}$ analysis was performed by DSM Nutrition Products (Parsippany, NJ).

\section{RESULTS}

Chemical analysis of experimental nursery diets confirmed that diets contained $\mathrm{CP}$ and $\mathrm{P}$ concentrations similar to those for which they were formulated (Table 2). The $\mathrm{Ca}$ concentrations analyzed higher than formulated, but all diets were above the animals' requirements. Although there is no published accepted standard for vitamin D recovery in animal feeds, analysis showed nursery diets were within $25 \%$ of their formulated targets, which would be consistent with the acceptable analytical variation and recovery of other vitamins previously discussed by the Association of American Feed Control Officials (2015).

\section{Growth Performance}

At weaning, BW of pigs subsampled for the nursery portion of the study increased (quadratic, $P=$ 0.001; Table 3) with increasing maternal vitamin $\mathrm{D}_{3}$. This occurred because pigs subsampled from sows fed the 2,000 IU of vitamin $\mathrm{D}_{3} / \mathrm{kg}$ were heavier (6.8 $\mathrm{kg})$ than pigs from sows fed either $800(6.5 \mathrm{~kg})$ or $9,600(6.6 \mathrm{~kg}) \mathrm{IU}$ of vitamin $\mathrm{D}_{3} / \mathrm{kg}$. In addition, pigs weaned from sows fed $800 \mathrm{IU}$ of vitamin $\mathrm{D}_{3} / \mathrm{kg}$ tended $(P=0.088)$ to have lighter BW at weaning than pigs weaned from sows fed $50 \mu \mathrm{g}$ of $25(\mathrm{OH}) \mathrm{D}_{3} / \mathrm{kg}$. For the maternal portion of the study, these numeric differences were not statistically significant, but changing the experimental unit from sow to pen led to a significant difference in initial BW among vitamin $\mathrm{D}_{3}$ treatments and a statistical tendency when comparing $\mathrm{BW}$ of pigs weaned from sows fed $800 \mathrm{IU}$ of vitamin $\mathrm{D}_{3} / \mathrm{kg}$ and pigs weaned from sows fed $50 \mu \mathrm{g}$ of $25(\mathrm{OH}) \mathrm{D}_{3} / \mathrm{kg}$.

No nursery $\times$ maternal vitamin $D$ interactions were observed for growth performance in the nursery or finishing portion of the growth study. Thus, only the main effects of maternal vitamin D treatment and nursery vitamin $\mathrm{D}$ treatments are reported herein.

Nursery dietary vitamin D regimen had no influence (Table 4) on pig growth throughout the nursery or finishing portion of the study. From d 0 to 35 in the nursery, increasing maternal vitamin $\mathrm{D}_{3}$ increased (quadratic, $P<0.003) \mathrm{ADG}$ and ADFI, but G:F was similar regardless of maternal vitamin $D$ regimen. Pigs weaned from sows fed $800 \mathrm{IU}$ of vitamin $\mathrm{D}_{3} / \mathrm{kg}$ had lower $(P=$ $0.002)$ ADG and tended $(P=0.066)$ to have lower ADFI than pigs weaned from sows fed $50 \mu \mathrm{g}$ of $25(\mathrm{OH}) \mathrm{D}_{3} / \mathrm{kg}$. Final BW at the end of the nursery period (d 35) was increased (quadratic, $P=0.001$ ) with increased maternal vitamin $\mathrm{D}_{3}$ because pigs from sows fed 2,000 IU of vitamin $\mathrm{D}_{3} / \mathrm{kg}$ had heavier BW at the end of the nursery compared with pigs from sows fed 800 or $9,600 \mathrm{IU}$ of vitamin $\mathrm{D}_{3} / \mathrm{kg}$. In addition, pigs from sows fed $800 \mathrm{IU}$ of vitamin $\mathrm{D}_{3} / \mathrm{kg}$ had lighter $(P=0.001)$ final $\mathrm{BW}$ at the end of the nursery period compared with pigs fed $50 \mu \mathrm{g}$ of $25(\mathrm{OH}) \mathrm{D}_{3} / \mathrm{kg}$. Overall finisher ADG increased (quadratic, $P=0.005$ ) with increased maternal vitamin $\mathrm{D}_{3}$, which also led to increased (quadratic, $P=0.006$ ) final BW. Similar to nursery growth, this was because pigs from sows fed 2,000 IU of vitamin $\mathrm{D}_{3} / \mathrm{kg}$ had increased ADG and improved G:F compared with pigs from sows fed 800 or $9,600 \mathrm{IU}$ of vitamin $\mathrm{D}_{3} / \mathrm{kg}$. Also, pigs from sows fed $800 \mathrm{IU}$ of vitamin $\mathrm{D}_{3} / \mathrm{kg}$ had lower $(P=0.004)$ ADG and lighter $(P=0.003)$ final BW com- 
Table 3. Main effects of maternal vitamin D regimen on the performance of growing pigs ${ }^{1}$

\begin{tabular}{|c|c|c|c|c|c|c|c|c|c|c|}
\hline \multirow[b]{3}{*}{ Item } & \multicolumn{4}{|c|}{ Maternal vitamin $\mathrm{D}, \mathrm{IU} / \mathrm{kg}$} & \multirow[b]{3}{*}{ SEM } & \multicolumn{5}{|c|}{ Probability P } \\
\hline & \multicolumn{3}{|c|}{ Vitamin $\mathrm{D}_{3}$} & \multirow{2}{*}{$\frac{50 \mu \mathrm{g} 25(\mathrm{OH}) \mathrm{D}_{3}}{2,000}$} & & \multicolumn{2}{|c|}{ Vitamin $\mathrm{D}_{3}$} & \multirow{2}{*}{$\begin{array}{c}800 \mathrm{IU} \mathrm{D}_{3} \text { vs. } 50 \\
\mu \mathrm{g} 25(\mathrm{OH}) \mathrm{D}_{3}\end{array}$} & \multirow{2}{*}{$\begin{array}{l}2,000 \mathrm{IU} \mathrm{D}_{3} \text { vs. } \\
50 \mu \mathrm{g} 25(\mathrm{OH}) \mathrm{D}_{3}\end{array}$} & \multirow{2}{*}{$\begin{array}{l}9,600 \mathrm{IU} \mathrm{D}_{3} \text { vs. } \\
50 \mu \mathrm{g} 25(\mathrm{OH}) \mathrm{D}_{3}\end{array}$} \\
\hline & 800 & 2,000 & 9,600 & & & Linear & Quadratic & & & \\
\hline \multicolumn{11}{|c|}{ Nursery growth (d 0 to 35$)^{2}$} \\
\hline $\mathrm{ADG}, \mathrm{kg}$ & 0.42 & 0.44 & 0.43 & 0.45 & 0.02 & $<0.729$ & $<0.003$ & $<0.002$ & $<0.917$ & $<0.105$ \\
\hline ADFI, kg & 0.65 & 0.70 & 0.67 & 0.69 & 0.02 & $<0.853$ & $<0.002$ & $<0.066$ & $<0.929$ & $<0.437$ \\
\hline G:F & 0.638 & 0.632 & 0.639 & 0.647 & 0.006 & $<0.708$ & $<0.407$ & $<0.709$ & $<0.236$ & $<0.709$ \\
\hline \multicolumn{11}{|c|}{ Finishing growth (d 35 to market) ${ }^{3}$} \\
\hline $\mathrm{ADG}, \mathrm{kg}$ & 0.93 & 0.96 & 0.94 & 0.96 & 0.01 & $<0.602$ & $<0.005$ & $<0.004$ & $<0.916$ & $<0.220$ \\
\hline ADFI, $\mathrm{kg}$ & 2.56 & 2.59 & 2.57 & 2.63 & 0.02 & $<0.981$ & $<0.492$ & $<0.216$ & $<0.558$ & $<0.327$ \\
\hline G:F & 0.368 & 0.377 & 0.374 & 0.373 & 0.006 & $<0.610$ & $<0.049$ & $<0.701$ & $<0.740$ & $<0.997$ \\
\hline \multicolumn{11}{|c|}{ Average BW, kg } \\
\hline $\mathrm{d} 0$ & 6.5 & 6.8 & 6.6 & 6.6 & 0.1 & $<0.566$ & $<0.001$ & $<0.088$ & $<0.371$ & $<0.985$ \\
\hline d 35 & 21.1 & 22.3 & 21.8 & 22.3 & 0.5 & $<0.555$ & $<0.001$ & $<0.001$ & $<0.997$ & $<0.141$ \\
\hline Market & 132.6 & 136.5 & 134.9 & 137.5 & 3.0 & $<0.480$ & $<0.006$ & $<0.003$ & $<0.866$ & $<0.240$ \\
\hline
\end{tabular}

${ }^{1} \mathrm{~A}$ total of 448 pigs from 52 litters in 2 farrowing groups were used in a 35-d nursery trial. The treatment structure was a split-plot design with maternal treatment as the whole-plot unit and nursery treatment as the split-plot unit.

${ }^{2}$ For nursery performance pen was the experimental unit. Random effect of group was used in the statistical model. There were 7 pigs per pen and 8 pens per treatment in group 1, and there were 4 pigs per pen and either 16 or 17 pens per treatment in group 2 .

${ }^{3}$ For finishing performance pen was the experimental unit. Random effect of group was used in the statistical model. There were a total of 5 to 8 pigs per pen and 19 finishing pens per treatment.

pared with pigs from sows fed $50 \mu \mathrm{g}$ of $25(\mathrm{OH}) \mathrm{D}_{3} / \mathrm{kg}$. Feed efficiency was improved (quadratic, $P=0.049$ ) with increasing maternal vitamin $\mathrm{D}_{3}$.

\section{Growing Pig Serum 25(OH)D, Vitamin $D_{3}$, a-Tocopherol, and Retinol}

No 3-way maternal $\times$ nursery $\times$ day interactions were observed for serum vitamin metabolite responses. Thus, only the main effects of maternal and nursery vitamin $\mathrm{D}$ regimens are reported herein.

A maternal treatment $\times$ day $(P<0.001$; Table 5) interaction was observed for growing pig serum $25(\mathrm{OH})$ $\mathrm{D}_{3}$ because changes in serum concentrations over time were dependent on the maternal dietary treatments. At weaning, increasing maternal dietary vitamin $\mathrm{D}_{3}$ increased (linear, $P=0.001$ ) serum $25(\mathrm{OH}) \mathrm{D}_{3}$ and (quadratic, $P=0.037$ ) serum retinol, but it decreased (linear, $P=0.037)$ serum $\alpha$-tocopherol. In addition, pigs from sows fed $9,600 \mathrm{IU}$ of vitamin $\mathrm{D}_{3} / \mathrm{kg}$ had increased $(P<$ $0.001)$ serum $25(\mathrm{OH}) \mathrm{D}_{3}$ compared with pigs from sows fed $50 \mu \mathrm{g}$ of $25(\mathrm{OH}) \mathrm{D}_{3} / \mathrm{kg}$. Pigs from sows fed 800 IU of vitamin $\mathrm{D}_{3} / \mathrm{kg}$ had increased $(P=0.001)$ serum $\alpha$-tocopherol compared with pigs from sows fed $50 \mu \mathrm{g}$ of $25(\mathrm{OH}) \mathrm{D}_{3} / \mathrm{kg}$. Also, increasing maternal dietary vitamin $\mathrm{D}_{3}$ supplementation led to an increased (quadratic, $P=$ 0.023 ) percentage of pigs exhibiting serum vitamin $D_{3}$ concentrations above the detectable limit with a decreasing (quadratic, $P=0.001$ ) mean vitamin $\mathrm{D}_{3}$ concentration. On d 17 after weaning, increasing maternal vitamin $\mathrm{D}_{3}$ increased (quadratic; $P=0.023$ ) serum retinol and tended (quadratic, $P=0.063$ ) to increase serum $25(\mathrm{OH})$
$\mathrm{D}_{3}$. Additionally, increasing maternal vitamin $\mathrm{D}_{3}$ supplementation tended (linear, $P=0.082$ ) to decrease piglet serum vitamin $\mathrm{D}_{3}$ concentrations, although the percentage of pigs exhibiting serum concentrations above the detectable limit was not affected by maternal vitamin $\mathrm{D}$ dietary treatment. By d 35 postweaning, increasing maternal vitamin $\mathrm{D}_{3}$ supplementation increased (quadratic, $P=0.006)$ serum $25(\mathrm{OH}) \mathrm{D}_{3}$ and tended (quadratic, $P=$ 0.063 ) to increase serum retinol. Also, pigs from sows fed 2,000 IU of vitamin $\mathrm{D}_{3} / \mathrm{kg}$ had increased $(P<0.002)$ serum $25(\mathrm{OH}) \mathrm{D}_{3}$ compared with pigs from sows fed 50 $\mu \mathrm{g}$ of $25(\mathrm{OH}) \mathrm{D}_{3} / \mathrm{kg}$. By d 70 after weaning, maternal dietary vitamin D treatment had no influence on growing pig serum vitamin metabolites.

A nursery $\times$ day $(P<0.001$; Table 6$)$ interaction was observed for growing pig serum $25(\mathrm{OH}) \mathrm{D}_{3}$ because changes over time were different on the basis of nursery vitamin $\mathrm{D}$ regimen. At weaning, pigs moved to pens fed vitamin $\mathrm{D}_{3}$ had lower $(P=0.015)$ serum $\alpha$-tocopherol concentrations than pigs moved to pens fed $25(\mathrm{OH}) \mathrm{D}_{3}$. Also, pigs moved to pens fed vitamin $\mathrm{D}_{3}$ tended $(P=$ $0.099)$ to have greater mean serum vitamin $\mathrm{D}_{3}$ concentrations, although the percentage of pigs exhibiting concentrations above the detectable limit was not influenced by nursery treatment. On d 17 and 35 in the nursery, pigs fed vitamin $\mathrm{D}_{3}$ had greater $(P<0.001)$ percentages of pigs exhibiting serum vitamin $\mathrm{D}_{3}$ concentrations above the detectable limit; however, they also had decreased serum $25(\mathrm{OH}) \mathrm{D}_{3}(P=0.001)$ concentrations compared with pigs fed $25(\mathrm{OH}) \mathrm{D}_{3}$. By d $70(35 \mathrm{~d}$ postnursery vitamin $\mathrm{D}$ treatments), serum vitamin metabolites were not influenced by nursery dietary vitamin $\mathrm{D}$ regimens. 
Table 4. Main effects of nursery dietary vitamin D regimen on the performance of growing pigs ${ }^{1}$

\begin{tabular}{|c|c|c|c|c|}
\hline \multirow[b]{2}{*}{ Item } & \multicolumn{2}{|c|}{ Nursery source $^{2}$} & \multirow[b]{2}{*}{ SEM } & \multirow{2}{*}{$\begin{array}{c}\text { Probability } P \\
\text { nursery }\end{array}$} \\
\hline & Vitamin $\mathrm{D}_{3}$ & $25(\mathrm{OH}) \mathrm{D}_{3}$ & & \\
\hline \multicolumn{5}{|c|}{ Nursery growth (d 0 to 35$)^{3}$} \\
\hline $\mathrm{ADG}, \mathrm{kg}$ & 0.44 & 0.43 & 0.02 & $<0.482$ \\
\hline ADFI, kg & 0.68 & 0.67 & 0.02 & $<0.137$ \\
\hline $\mathrm{G}: \mathrm{F}$ & 0.635 & 0.643 & 0.004 & $<0.224$ \\
\hline \multicolumn{5}{|c|}{ Finishing growth (d 35 to market) ${ }^{4}$} \\
\hline $\mathrm{ADG}, \mathrm{kg}$ & 0.95 & 0.95 & 0.01 & $<0.577$ \\
\hline ADFI, kg & 2.57 & 2.61 & 0.02 & $<0.126$ \\
\hline G:F & 0.374 & 0.369 & 0.006 & $<0.453$ \\
\hline \multicolumn{5}{|c|}{ Average BW, kg } \\
\hline d 0 & 6.6 & 6.6 & 0.1 & $<0.922$ \\
\hline d 35 & 21.9 & 21.8 & 0.5 & $<0.537$ \\
\hline Market & 135.3 & 135.4 & 2.9 & $<0.911$ \\
\hline
\end{tabular}

${ }^{1} \mathrm{~A}$ total of 448 pigs from 52 litters in 2 farrowing groups were used in a 35 -d nursery trial. The treatment structure was a split-plot design with maternal treatment as the whole-plot unit and nursery treatment as the split-plot unit.

${ }^{2}$ Subsequent nursery treatments consisted of supplementing vitamin $\mathrm{D}$ in phase 1,2 , and 3 diets from either vitamin $\mathrm{D}_{3}(2,000 \mathrm{IU} / \mathrm{kg})$ or $25(\mathrm{OH}) \mathrm{D}_{3}$ $(50 \mu \mathrm{g} / \mathrm{kg})$.

${ }^{3}$ For nursery performance pen was the experimental unit. Random effect of group was used in the statistical model. There were a total of 7 pigs per pen and 16 pens per treatment in group 1 , and there were 4 pigs per pen and 33 pens per treatment in group 2 .

${ }^{4}$ For finishing performance pen was the experimental unit. Random effect of group was used in the statistical model. There were a total of 5 to 8 pigs per pen and 38 finishing pens per treatment.

\section{Carcass Characteristics}

Pigs from sows fed $50 \mu \mathrm{g}$ of $25(\mathrm{OH}) \mathrm{D}_{3} / \mathrm{kg}$ had heavier $(P<0.047$; Table 7$)$ final live BW and HCW than pigs from sows fed $9,600 \mathrm{IU}$ of vitamin $\mathrm{D}_{3} / \mathrm{kg}$. Carcass yield percentage increased (quadratic, $P=$ 0.003 ) with increasing maternal dietary vitamin $\mathrm{D}_{3}$ supplementation. Loin depth (linear, $P=0.047$ ) and back fat thickness (quadratic, $P=0.031$ ) decreased with increasing maternal dietary vitamin $\mathrm{D}_{3}$ supplementation.

\section{DISCUSSION}

The impact of maternal imprinting on postnatal performance of progeny has led to an increased interest in understanding how maternal nutrition can impact subsequent progeny growth. Mahan and Vallet (1997) concluded that the understanding of vitamin and mineral transport in utero was still very much in its infancy almost 2 decades ago. Research specifically focused on vitamin D's transport and function in utero has been more prolific than research on some other vitamins and trace minerals.

Haddad et al. (1971) illustrated, using pregnant rats, that both vitamin $\mathrm{D}_{3}$ and $25(\mathrm{OH}) \mathrm{D}_{3}$ are capable of being transported transplacentally to the fetus and concluded that maternal and fetal ratios of vitamin $D_{3}$ and $25(\mathrm{OH}) \mathrm{D}_{3}$ were similar as soon as $1 \mathrm{~h}$ after administration. Clements and Fraser (1988) determined that supplementing vitamin $\mathrm{D}$ deficient pregnant rats resulted in increased in utero presence of vitamin D metabolites, predominately $25(\mathrm{OH}) \mathrm{D}_{3}$ and $24,25-\mathrm{OH} 2-\mathrm{D}_{3}$. The active form of the vitamin $\left(1,25-\mathrm{OH} 2-\mathrm{D}_{3}\right)$ must be derived from fetal sources, but little to no data are available about how the active form is metabolized in the fetus. However, Johnson et al. (1996) and Endo et al. (2003) both illustrated the presence of vitamin D nuclear receptors (VDR) within fetal bone and muscle tissues. This suggests that the active $1,25-\mathrm{OH} 2-\mathrm{D}_{3}$ metabolite plays a role in the fetal development of these tissues. In fact, Endo et al. (2003) demonstrated that the absence of the VDR in mice led to aberrant expression of myogenic transcription factors (myogenic factor 5 positive cells [Myf5], myogenin, and early lymphocyte cells in development [E2A]) in hind leg muscle. High expression of these factors in utero could lead to precocious cell differentiation and impaired cell proliferation, leaving a smaller myoblast cell pool for postnatal muscle development and hypertrophic growth. Most of this research has been conducted with deficient animals; however, previous work in swine by Hines et al. (2013) concluded that differences in fetal muscle fiber number and Pax7+ cells existed within the LM of fetuses from bred gilts fed 2,500 IU of vitamin D/kg of diet as $100 \%$ vitamin $\mathrm{D}_{3}$ or as $80 \% 25(\mathrm{OH}) \mathrm{D}_{3}$ and $20 \%$ vitamin $\mathrm{D}_{3}$. Their conclusion was that the increases in maternal $25(\mathrm{OH}) \mathrm{D}_{3}$ concentrations (vitamin $\mathrm{D}$ status) were the reason for the improvements in fetal muscle development. Other researchers have observed similar increases in the serum $25(\mathrm{OH}) \mathrm{D}_{3}$ response of growing pigs and sows fed $25(\mathrm{OH}) \mathrm{D}_{3}$ compared with those fed similar IU equivalency concentrations of vitamin $\mathrm{D}_{3}$. The aforementioned conclusions from previous research led to our hypothesis that altering the maternal vitamin D status of the sow could lead to alterations in fetal muscle development and, subsequently, changes in postnatal growth. The aim of the study herein was to evaluate the postnatal growth of pigs from sows fed the varying dietary vitamin $\mathrm{D}$ supplementation treatments and to determine whether growth was impacted by maternal dietary vitamin $\mathrm{D}$ treatment and/or by subsequent nursery dietary vitamin $\mathrm{D}$ treatments.

Nursery and finishing growth herein was not influenced by nursery vitamin $\mathrm{D}$ supplementation, which is consistent with conclusions reported by Wahlstrom and Stolte (1958), Combs et al. (1966), and Flohr et al. (2014b), who evaluated supplementing dietary vitamin $\mathrm{D}_{3}$ when all other nutrient concentrations were adequate. Rortvedt and Crenshaw (2012) demonstrated a 10\% reduction in the growth of nursery pigs weaned from sows fed diets deficient (45 IU vitamin $\mathrm{D}_{3} / \mathrm{kg}$ of diet) in vita- 
Table 5. Main effects of maternal dietary vitamin D regimen on growing pig serum metabolites ${ }^{1}$

\begin{tabular}{|c|c|c|c|c|c|c|c|c|c|c|}
\hline \multirow{3}{*}{$\begin{array}{l}\text { Growing pig } \\
\text { serum vitamin } \\
\text { metabolites }\end{array}$} & \multicolumn{4}{|c|}{ Maternal vitamin $\mathrm{D}, \mathrm{IU} / \mathrm{kg}$} & \multirow[b]{3}{*}{ SEM } & \multicolumn{5}{|c|}{ Probability $P$} \\
\hline & \multicolumn{3}{|c|}{ Vitamin $\mathrm{D}_{3}$} & \multirow{2}{*}{$\frac{50 \mu \mathrm{g} 25(\mathrm{OH}) \mathrm{D}_{3}}{2,000}$} & & \multicolumn{2}{|c|}{ Vitamin $\mathrm{D}_{3}$} & \multirow{2}{*}{$\begin{array}{c}800 \mathrm{IU} \mathrm{D}_{3} \text { vs. } 50 \\
\mu \mathrm{g} 25(\mathrm{OH}) \mathrm{D}_{3}\end{array}$} & \multirow{2}{*}{$\begin{array}{l}2,000 \mathrm{IU} \mathrm{D}_{3} \text { vs. } \\
50 \mu \mathrm{g} 25(\mathrm{OH}) \mathrm{D}_{3}\end{array}$} & \multirow{2}{*}{$\begin{array}{l}9,600 \mathrm{IU} \mathrm{D}_{3} \mathrm{vs} . \\
50 \mu \mathrm{g} 25(\mathrm{OH}) \mathrm{D}_{3}\end{array}$} \\
\hline & 800 & 2,000 & 9,600 & & & Linear & Quadratic & & & \\
\hline \multicolumn{11}{|l|}{$25(\mathrm{OH}) \mathrm{D}_{3},{ }^{2} \mathrm{ng} / \mathrm{mL}$} \\
\hline Weaning & 5.4 & 7.1 & 16.6 & 5.5 & 1.2 & $<0.001$ & $<0.871$ & $<0.925$ & $<0.300$ & $<0.001$ \\
\hline d 17 & 22.7 & 25.9 & 25.0 & 23.6 & 1.2 & $<0.466$ & $<0.063$ & $<0.581$ & $<0.163$ & $<0.398$ \\
\hline d 35 & 26.4 & 30.8 & 26.8 & 25.5 & 1.3 & $<0.366$ & $<0.006$ & $<0.556$ & $<0.002$ & $<0.452$ \\
\hline $\mathrm{d} 70$ & 18.3 & 15.7 & 16.1 & 16.5 & 1.5 & $<0.497$ & $<0.257$ & $<0.403$ & $<0.686$ & $<0.816$ \\
\hline \multicolumn{11}{|l|}{ Vitamin $\mathrm{D}_{3}{ }^{3}$} \\
\hline \multicolumn{11}{|l|}{ Weaning } \\
\hline Detectable samples, $\%$ & 6.3 & 32.4 & 83.3 & 0.0 & 5.2 & $<0.001$ & $<0.023$ & $<0.395$ & $<0.001$ & $<0.001$ \\
\hline Mean, ng/mL & 7.3 & 1.2 & 5.6 & - & 0.2 & $<0.369$ & $<0.001$ & - & - & - \\
\hline \multicolumn{11}{|l|}{ d 17} \\
\hline Detectable samples, $\%$ & 43.8 & 43.8 & 50.0 & 50.0 & 5.7 & $<0.367$ & $<0.907$ & $<0.420$ & $<0.420$ & $<0.999$ \\
\hline Mean, ng/mL & 3.3 & 3.8 & 2.7 & 3.0 & 0.4 & $<0.082$ & $<0.266$ & $<0.505$ & $<0.114$ & $<0.614$ \\
\hline \multicolumn{11}{|l|}{ d 35} \\
\hline Detectable samples, $\%$ & 43.8 & 50.0 & 50.0 & 50.0 & 5.9 & $<0.593$ & $<0.459$ & $<0.420$ & $<0.999$ & $<0.999$ \\
\hline Mean, ng/mL & 3.5 & 3.5 & 3.6 & 3.8 & 0.4 & $<0.888$ & $<0.920$ & $<0.590$ & $<0.521$ & $<0.641$ \\
\hline \multicolumn{11}{|l|}{$\mathrm{d} 70$} \\
\hline Detectable samples, $\%$ & 100.0 & 100.0 & 100.0 & 100.0 & 7.1 & $<0.999$ & $<0.999$ & $<0.999$ & $<0.999$ & $<0.999$ \\
\hline Mean, ng/mL & 3.2 & 3.1 & 3.1 & 2.6 & 0.3 & $<0.855$ & $<0.784$ & $<0.191$ & $<0.312$ & $<0.277$ \\
\hline \multicolumn{11}{|l|}{$\alpha$-tocopherol, ${ }^{4} \mathrm{mg} / \mathrm{L}$} \\
\hline Weaning & 5,304 & 4,769 & 4,591 & 4,331 & 198 & $<0.037$ & $<0.086$ & $<0.001$ & $<0.101$ & $<0.340$ \\
\hline d 17 & 982 & 829 & 804 & 924 & 207 & $<0.641$ & $<0.629$ & $<0.837$ & $<0.738$ & $<0.679$ \\
\hline d 35 & 1,521 & 1,401 & 1,242 & 1,291 & 216 & $<0.374$ & $<0.758$ & $<0.417$ & $<0.698$ & $<0.869$ \\
\hline d 70 & 1,799 & 1,566 & 1,784 & 1,631 & 259 & $<0.796$ & $<0.498$ & $<0.632$ & $<0.856$ & $<0.646$ \\
\hline \multicolumn{11}{|l|}{ Retinol, ${ }^{5} \mathrm{ng} / \mathrm{mL}$} \\
\hline Weaning & 254 & 301 & 286 & 283 & 20 & $<0.464$ & $<0.037$ & $<0.176$ & $<0.427$ & $<0.907$ \\
\hline d 17 & 366 & 419 & 397 & 413 & 21 & $<0.599$ & $<0.023$ & $<0.038$ & $<0.795$ & $<0.491$ \\
\hline d 35 & 389 & 435 & 431 & 421 & 22 & $<0.242$ & $<0.063$ & $<0.158$ & $<0.553$ & $<0.667$ \\
\hline $\mathrm{d} 70$ & 379 & 393 & 373 & 360 & 25 & $<0.635$ & $<0.585$ & $<0.507$ & $<0.250$ & $<0.631$ \\
\hline
\end{tabular}

${ }^{1}$ A total of 448 pigs from 52 litters in 2 farrowing groups were used in a 35-d nursery trial and followed through finishing. The treatment structure was a split-plot design with maternal treatment as the whole-plot unit and nursery treatment as the split-plot unit.

${ }^{2}$ A maternal $\times$ day $(P<0.001)$ interaction was observed for growing pig serum $25(\mathrm{OH}) \mathrm{D}_{3}$ concentrations.

${ }^{3}$ The assay for serum vitamin $\mathrm{D}_{3}$ had a lower detectable limit of $1.00 \mathrm{ng} / \mathrm{mL}$. Samples below the detectable limit $(n=130$ out of 256$)$ were not used in the statistical analysis. Detectable sample represents the percentage of samples above the detectable limit, and the mean serum vitamin $\mathrm{D}_{3}$ was calculated using only samples above the detectable limit.

${ }^{4} \mathrm{~A}$ day effect $(P<0.001)$ was observed for growing pig serum $\boldsymbol{\alpha}$-tocopherol concentrations.

${ }^{5} \mathrm{~A}$ day effect $(P<0.001)$ was observed for growing pig serum retinol concentrations.

min D compared with pigs weaned from sows fed diets formulated to $325 \mathrm{IU}$ vitamin $\mathrm{D}_{3} / \mathrm{kg}$ of feed. The authors concluded that pigs born from sows fed diets deficient in vitamin $\mathrm{D}$ were unable to achieve performance comparable to that of pigs born from sows fed diets replete with vitamin $\mathrm{D}$, regardless of $\mathrm{Ca}$ and $\mathrm{P}$ supplementation after weaning (the researchers evaluated feeding $80 \%$ or $120 \%$ of the animal's estimated requirement [NRC, 1998]). This suggests a role of vitamin D in utero and the potential for deficiency to impact postnatal development.

Interestingly, in the study herein, maternal vitamin D influenced postweaning growth but not in the way that we had hypothesized on the basis of previous conclusions drawn from Hines et al. (2013) and Weber et al. (2014). In the current study, it appeared that the only consistent impact on growth performance was that pigs from sows fed 2,000 IU of vitamin $\mathrm{D}_{3} / \mathrm{kg}$ had increased ADG and ADFI in the nursery and improved ADG and $\mathrm{G}: \mathrm{F}$ in finishing. Considering that performance of pigs from sows fed $50 \mu \mathrm{g}$ of $25(\mathrm{OH}) \mathrm{D}_{3}$ was similar to that of pigs from sows fed $2,000 \mathrm{IU}$ of vitamin $\mathrm{D}_{3} / \mathrm{kg}$, the conclusion is that the form of maternal vitamin D (vita$\min \mathrm{D}_{3}$ or $25(\mathrm{OH}) \mathrm{D}_{3}$ ) does not influence postweaning growth; however, it appeared that the level of the vitamin supplemented did result in growth differences. The data herein suggest that 2,000 IU of vitamin D/kg of diet were useful in achieving the highest growth rates compared to feeding 800 or $9,600 \mathrm{IU}$ of vitamin $\mathrm{D}_{3} / \mathrm{kg}$. Also, pigs weaned from sows fed 2,000 IU of vitamin $\mathrm{D}_{3} / \mathrm{kg}$ had numerically heavier weaning BW (although not 
statistically significant in the sow portion of the study; Flohr et al., 2016) than pigs from sows fed 800 or 9,600 IU of vitamin $D_{3} / \mathrm{kg}$. Pluske and Dong (1998) showed that the growth of suckling pig is predominately limited by the amount of milk produced by the sow. In addition, the amount of feed intake during lactation can impact total milk production and subsequent litter weaning weight (Eissen et al., 2003). Because of the increase in lactation ADFI observed for sows fed diets with 2,000 IU of vitamin $\mathrm{D}_{3} / \mathrm{kg}$ discussed by Flohr et al. (2016), it is plausible to think that lactation feed intake may have been a larger reason for the numeric increase in weaning weights of pigs rather than maternal vitamin $\mathrm{D}$ treatment. There is no previous evidence to support that maternal vitamin D treatment would have impacted lactation feed intake except for the case of toxicity, which has been described to cause lethargy and anorexia (NRC, 1988); however, signs of these symptoms were not observed during the lactation portion of the study. Ultimately, the results herein suggest that maternal dietary vitamin D treatment impacted nursery performance, which disagrees with the results of Flohr et al. (2014a), who observed no impact of maternal vitamin $\mathrm{D}_{3}$ treatment or nursery vitamin $\mathrm{D}_{3}$ treatment on nursery performance of pigs weaned from sows supplemented between 1,500 and $6,000 \mathrm{IU}$ of vitamin $\mathrm{D}_{3} / \mathrm{kg}$ of diet.

The maternal and nursery vitamin $\mathrm{D}$ treatment impacts on growing pig serum $25(\mathrm{OH}) \mathrm{D}_{3}$ in this study were largely expected. Most previous reports (Lauridsen et al., 2010; Witschi et al., 2011; Coffey et al., 2012; Weber et al., 2014) have all shown that supplementation of $25(\mathrm{OH}) \mathrm{D}_{3}$ at the same IU equivalency of vitamin $\mathrm{D}_{3}$ will result in an increased serum $25(\mathrm{OH})$ $\mathrm{D}_{3}$ response. Also, increasing maternal vitamin $\mathrm{D}_{3}$ supplementation has been shown to lead to an increase in subsequent pig serum $25(\mathrm{OH}) \mathrm{D}_{3}$ (Flohr et al., 2014a), which is consistent with results from the current study. However, pigs weaned from sows fed $50 \mu \mathrm{g}$ of $25(\mathrm{OH})$ $\mathrm{D}_{3} / \mathrm{kg}$ had serum $25(\mathrm{OH}) \mathrm{D}_{3}$ concentrations similar to those of pigs weaned from sows fed 2,000 IU of vita$\min \mathrm{D}_{3} / \mathrm{kg}$ (which were formulated to be at the same IU equivalency of the vitamin), but levels were less than that of pigs from sows fed $9,600 \mathrm{IU}$ of vitamin $\mathrm{D}_{3} / \mathrm{kg}$. This shows that for milk transfer of the vitamin (which was the lone source of the nutrient prior to weaning) the level of maternal dietary vitamin D was more impactful than the form of dietary vitamin $\mathrm{D}$. Additionally, Flohr et al. (2014a) concluded that serum $25(\mathrm{OH}) \mathrm{D}_{3}$ of weaned pigs was no longer impacted by maternal vitamin $D_{3}$ supplementation as soon as $21 \mathrm{~d}$ postweaning. However, maternal vitamin $\mathrm{D}$ treatment impacted serum $25(\mathrm{OH}) \mathrm{D}_{3}$ of growing pigs up to $35 \mathrm{~d}$ postweaning in the current study. This may be largely due to, in part, the increase in ADFI of pigs weaned from sows
Table 6. Main effects of nursery dietary vitamin D regimen on growing pig serum vitamin metabolites ${ }^{1}$

\begin{tabular}{|c|c|c|c|c|}
\hline \multirow{2}{*}{$\begin{array}{l}\text { Growing pig serum vitamin } \\
\text { metabolites }\end{array}$} & \multicolumn{2}{|c|}{ Nursery source $^{2}$} & \multirow[b]{2}{*}{ SEM } & \multirow{2}{*}{$\begin{array}{c}\text { Probability } P \\
\text { nursery }\end{array}$} \\
\hline & Vitamin D & $25(\mathrm{OH}) \mathrm{D}_{3}$ & & \\
\hline \multicolumn{5}{|l|}{$25(\mathrm{OH}) \mathrm{D}_{3},{ }^{3} \mathrm{ng} / \mathrm{mL}$} \\
\hline Weaning & 9.3 & 8.0 & 0.8 & $<0.229$ \\
\hline d 17 & 11.3 & 37.3 & 0.9 & $<0.001$ \\
\hline d 35 & 16.1 & 38.7 & 0.9 & $<0.001$ \\
\hline $\mathrm{d} 70$ & 16.8 & 16.6 & 1.1 & $<0.889$ \\
\hline \multicolumn{5}{|l|}{ Vitamin $\mathrm{D}_{3},{ }^{4} \mathrm{ng} / \mathrm{mL}$} \\
\hline \multicolumn{5}{|l|}{ Weaning } \\
\hline Detectable samples, $\%$ & 33.3 & 27.0 & 4.7 & $<0.335$ \\
\hline Mean, $\mathrm{ng} / \mathrm{mL}$ & 4.9 & 4.0 & 0.4 & $<0.099$ \\
\hline \multicolumn{5}{|l|}{ d 17} \\
\hline Detectable samples, $\%$ & 93.8 & 0.0 & 5.0 & $<0.001$ \\
\hline Mean, $\mathrm{ng} / \mathrm{mL}$ & 3.2 & - & 0.3 & - \\
\hline \multicolumn{5}{|l|}{ d 35} \\
\hline Detectable samples, $\%$ & 96.9 & 0.0 & 5.1 & $<0.001$ \\
\hline Mean, $\mathrm{ng} / \mathrm{mL}$ & 3.6 & - & 0.3 & - \\
\hline \multicolumn{5}{|l|}{$\mathrm{d} 70$} \\
\hline Detectable samples, $\%$ & 100.0 & 100.0 & 6.0 & $<0.999$ \\
\hline Mean, $\mathrm{ng} / \mathrm{mL}$ & 3.0 & 3.1 & 0.3 & $<0.823$ \\
\hline \multicolumn{5}{|l|}{$\alpha$-Tocopherol, ${ }^{5} \mathrm{mg} / \mathrm{L}$} \\
\hline Weaning & 4,512 & 4,984 & 138 & $<0.015$ \\
\hline d 17 & 902 & 868 & 145 & $<0.868$ \\
\hline d 35 & 1,404 & 1,324 & 148 & $<0.695$ \\
\hline $\mathrm{d} 70$ & 1,680 & 1,710 & 178 & $<0.901$ \\
\hline \multicolumn{5}{|l|}{ Retinol, ${ }^{6} \mathrm{ng} / \mathrm{mL}$} \\
\hline Weaning & 284 & 278 & 17 & $<0.663$ \\
\hline d 17 & 408 & 390 & 17 & $<0.260$ \\
\hline d 35 & 423 & 415 & 17 & $<0.660$ \\
\hline $\mathrm{d} 70$ & 373 & 379 & 20 & $<0.800$ \\
\hline
\end{tabular}

${ }^{1} \mathrm{~A}$ total of 448 pigs from 52 litters in 2 farrowing groups were used in a 35-d nursery trial and followed through finishing. The treatment structure was a split-plot design with maternal treatment as the whole-plot unit and nursery treatment as the split-plot unit.

${ }^{2}$ Subsequent nursery treatments consisted of supplementing vitamin D in phase 1,2 , and 3 diets from either vitamin $\mathrm{D}_{3}(2,000 \mathrm{IU} / \mathrm{kg})$ or $25(\mathrm{OH})$ $\mathrm{D}_{3}(50 \mu \mathrm{g} / \mathrm{kg})$.

${ }^{3}$ A nursery $\times$ day $(P<0.001)$ interaction was observed for growing pig serum $25(\mathrm{OH}) \mathrm{D}_{3}$ concentrations.

${ }^{4}$ The assay for serum vitamin $\mathrm{D}_{3}$ had a lower detectable limit of 1.00 $\mathrm{ng} / \mathrm{mL}$. Samples below the detectable limit ( $n=130$ out of 256 ) were not used in the statistical analysis. Positive sample represents the percentage of samples above the detectable limit, and the mean serum vitamin $\mathrm{D}_{3}$ was calculated using only samples above the detectable limit.

${ }^{5} \mathrm{~A}$ day effect $(P<0.001)$ was observed for growing pig serum $\boldsymbol{\alpha}$-tocopherol concentrations.

${ }^{6}$ A day effect $(P<0.001)$ was observed for growing pig serum retinol concentrations.

fed the medium level of vitamin $\mathrm{D}_{3}$, which would have increased total vitamin $\mathrm{D}$ intake.

Serum vitamin $\mathrm{D}_{3}$ concentrations responded as expected in growing pigs on the basis of maternal and nursery vitamin D treatments. Particularly, supplementing only $25(\mathrm{OH}) \mathrm{D}_{3}$, maternally or in the nursery diet, led to decreased serum vitamin $\mathrm{D}_{3}$ concentra- 
Table 7. The effect of maternal dietary vitamin D regimen on subsequent pig carcass characteristics ${ }^{1}$

\begin{tabular}{|c|c|c|c|c|c|c|c|c|c|c|}
\hline \multirow[b]{3}{*}{ Item } & \multicolumn{4}{|c|}{ Maternal vitamin $\mathrm{D},{ }^{2} \mathrm{IU} / \mathrm{kg}$} & \multirow[b]{3}{*}{ SEM } & \multicolumn{5}{|c|}{ Probability $P$} \\
\hline & \multicolumn{3}{|c|}{ Vitamin $\mathrm{D}_{3}$} & \multirow{2}{*}{$\frac{50 \mu \mathrm{g} 25(\mathrm{OH}) \mathrm{D}_{3}}{2,000}$} & & \multicolumn{2}{|c|}{ Vitamin $D_{3}$} & \multirow{2}{*}{$\begin{array}{c}800 \mathrm{IU} \mathrm{D}_{3} \text { vs. } 50 \\
\mu \mathrm{g} 25(\mathrm{OH}) \mathrm{D}_{3}\end{array}$} & \multirow{2}{*}{$\begin{array}{c}2,000 \mathrm{IU} \mathrm{D}_{3} \text { vs. } \\
50 \mu \mathrm{g} 25(\mathrm{OH}) \mathrm{D}_{3}\end{array}$} & \multirow{2}{*}{$\begin{array}{c}9,600 \mathrm{IU} \mathrm{D}_{3} \text { vs. } \\
50 \mu \mathrm{g} 25(\mathrm{OH}) \mathrm{D}_{3}\end{array}$} \\
\hline & 800 & 2,000 & 9,600 & & & Linear & Quadratic & & & \\
\hline Live BW, kg & 134.8 & 135.5 & 133.8 & 137.1 & 3.2 & $<0.264$ & $<0.534$ & $<0.266$ & $<0.574$ & $<0.047$ \\
\hline $\mathrm{HCW},{ }^{3} \mathrm{~kg}$ & 99.8 & 100.7 & 98.9 & 101.6 & 3.4 & $<0.155$ & $<0.288$ & $<0.276$ & $<0.830$ & $<0.037$ \\
\hline Yield, \% & 73.9 & 74.3 & 73.8 & 74.0 & 0.8 & $<0.077$ & $<0.002$ & $<0.521$ & $<0.339$ & $<0.298$ \\
\hline Loin depth, $\mathrm{mm}^{3}$ & 60.2 & 60.6 & 58.9 & 59.4 & 4.1 & $<0.037$ & $<0.470$ & $<0.743$ & $<0.457$ & $<0.905$ \\
\hline Back fat, $\mathrm{mm}^{3}$ & 20.8 & 19.7 & 20.3 & 20.0 & 0.9 & $<0.923$ & $<0.031$ & $<0.407$ & $<0.898$ & $<0.941$ \\
\hline
\end{tabular}

${ }^{1}$ Means represent data collected from 642 finishing pigs within 3 consecutive finishing groups. Group and finishing treatment within group were used as random effects.

${ }^{2}$ Maternal vitamin $\mathrm{D}_{3}$ concentrations of $800,2,000$, and 9,600 IU vitamin $\mathrm{D}_{3}$ per kilogram of complete diet were fed for low, medium, and treatments, respectively, and $50 \mu \mathrm{g}$ of $25(\mathrm{OH}) \mathrm{D}_{3} / \mathrm{kg}$ of complete diet was fed for the maternal $25(\mathrm{OH}) \mathrm{D}_{3}$ treatment.

${ }^{3}$ Hot carcass weight was used as a covariate in the statistical model.

tions in the growing pig. This result is expected because the demand for transport of vitamin $\mathrm{D}_{3}$ to tissue for storage or to the liver for metabolism is lessened if the animal is not exposed to that specific metabolite. However, it is difficult to infer much about the animal's vitamin $\mathrm{D}$ status from serum vitamin $\mathrm{D}_{3}$ concentrations since circulating levels will increase quickly after a meal and then clear circulation within hours after absorption (Clinton, 2013).

Little research has examined metabolic interactions of vitamin D with vitamin A and vitamin E. It was hypothesized that differences among serum retinol and $\alpha$-tocopherol based on maternal or nursery vitamin D treatment would be minimal and that was largely true. Interestingly, increased growing pig serum retinol after weaning was observed for pigs from sows fed 2,000 IU of vitamin $\mathrm{D}_{3} / \mathrm{kg}$ compared with pigs from sows fed either 800 or $9,600 \mathrm{IU}$ of vitamin $\mathrm{D}_{3} / \mathrm{kg}$. This may be the result of the increased lactation ADFI of sows fed diets containing 2,000 IU of vitamin $\mathrm{D}_{3} / \mathrm{kg}$ compared with sows fed diets containing 800 or 9,600 IU of vitamin $\mathrm{D}_{3} / \mathrm{kg}$. Daily vitamin A intake would have been approximately $650 \mathrm{IU} / \mathrm{d}$ greater for sows fed diets containing 2,000 IU of vitamin $\mathrm{D}_{3} / \mathrm{kg}$ compared with sows fed diets containing 800 or $9,600 \mathrm{IU}$ of vitamin $\mathrm{D}_{3} / \mathrm{kg}$.

The carcass data herein showed that pigs from sows fed $50 \mu \mathrm{g}$ of $25(\mathrm{OH}) \mathrm{D}_{3} / \mathrm{kg}$ had increased final BW and HCW compared to pigs from sows fed 9,600 IU of vitamin $\mathrm{D}_{3} / \mathrm{kg}$. Ultimately, this result was unexpected and, to our knowledge, is the first data associating subsequent pig carcass data with maternal dietary vitamin D supplementation. Increases in carcass yield and decreases in back fat of pigs from sows fed 2,000 IU of vitamin $\mathrm{D}_{3} / \mathrm{kg}$ compared with pigs from sows fed 800 or 9,600 IU of vitamin $\mathrm{D}_{3} / \mathrm{kg}$ compliment the growth data herein, suggesting pigs from sows fed 2,000 IU of vitamin $\mathrm{D}_{3}$ had both improved postweaning growth and improved carcass characteristics. However, it is still unclear whether these responses were the result of maternal vitamin D treat- ments or numeric differences in weaning weight of pigs weaned from sows fed the medium level of vitamin D.

\section{Conclusion}

Serum $25(\mathrm{OH}) \mathrm{D}_{3}$ of growing pigs is influenced by maternal dietary vitamin $\mathrm{D}$ treatment early after weaning, but afterward, it is largely dependent on nursery dietary vitamin $\mathrm{D}$ supplementation. Growing pigs fed $25(\mathrm{OH}) \mathrm{D}_{3}$ in the nursery had increased serum $25(\mathrm{OH})$ $\mathrm{D}_{3}$ compared with pigs fed vitamin $\mathrm{D}_{3}$ at the same IU equivalency, but by $35 \mathrm{~d}$ after nursery treatment serum levels were similar regardless of nursery vitamin D source. Also in this study, pigs from sows fed 2,000 IU of vitamin $\mathrm{D}_{3} / \mathrm{kg}$ had increased ADG and ADFI in the nursery, increased ADG and G:F in finishing, and increased percentage carcass yield and decreased back fat compared with pigs from sows fed 800 or 9,600 IU of vitamin $\mathrm{D}_{3} / \mathrm{kg}$. These results show a benefit to supplementing maternal vitamin $\mathrm{D}_{3}$ at $2,000 \mathrm{IU} / \mathrm{kg}$ of diet compared with 800 or $9,600 \mathrm{IU} / \mathrm{kg}$ of diet. In addition, ADG was improved for pigs weaned from sows fed $50 \mu \mathrm{g}$ of $25(\mathrm{OH}) \mathrm{D}_{3} / \mathrm{kg}$ compared with pigs weaned from sows fed $800 \mathrm{IU}$ of vitamin $\mathrm{D}_{3} / \mathrm{kg}$, and carcass data suggested that pigs weaned from sows fed $50 \mu \mathrm{g}$ of $25(\mathrm{OH}) \mathrm{D}_{3} / \mathrm{kg}$ had increased final $\mathrm{BW}$ and $\mathrm{HCW}$ compared with pigs from sows fed 9,600 IU/kg. More research examining the potential relationships of maternal vitamin D supplementation with subsequent pig growth and carcass characteristics is needed to elucidate if there are potential benefits of maternal vitamin D supplementation strategies different from those currently employed in commercial sow diets.

\section{LITERATURE CITED}

Association of American Feed Control Officials. 2015. 2015 Official publication. Assoc. Am. Feed Control Off. p. 302. 
Clements, M. R., and D. R. Fraser. 1988. Vitamin D supply to the rat fetus and neonate. J. Clin. Invest. 81:1768-1773. doi:10.1172/ JCI113518

Clinton, S. K. 2013. Vitamin D. In: M. H. Stipanuk and M. A. Caudill, editors, Biochemical, physiological, and molecular aspects of human nutrition. 3rd ed. Elsevier Saunders, St. Louis, MO. p. 703-717.

Coffey, J. D., E. A. Hines, J. D. Starkey, C. W. Starkey, and T. K. Chung. 2012. Feeding 25-hydroxycholecalciferol improves gilt reproductive performance and fetal vitamin D status. J. Anim. Sci. 90:3783-3788. doi:10.2527/jas.2011-5023

Combs, G. E., T. H. Berry, H. D. Wallace, and R. C. Cruml Jr. 1966. Influence of supplemental vitamin D on gain, nutrient digestibility and tissue composition of young pigs. J. Anim. Sci. 25:48-51. doi: $10.2527 /$ jas $1966.25148 \mathrm{x}$

Dwyer, C. M., J. M. Fletcher, and N. C. Stickland. 1993. Muscle cellularity and postnatal growth in the pig. J. Anim. Sci. 71:3339 3343.

Dwyer, C. M., N. C. Stickland, and J. M. Fletcher. 1994. The influence of maternal nutrition on muscle fiber number development in the porcine fetus and on subsequent postnatal growth. J. Anim. Sci. 72:911-917.

Eissen, J. J., E. J. Apeldoorn, E. Kanis, M. W. A. Verstegen, and K. H. de Greef. 2003. The importance of high feed intake during lactation of primiparous sows nursing large litters. J. Anim. Sci. 81:594-603. doi:10.2527/2003.813594x

Endo, I., D. Inoue, T. Mitsui, Y. Umaki, M. Akaike, T. Yoshizawa, S. Kato, and T. Matsumoto. 2003. Deletion of vitamin D receptor gene in mice results in abnormal skeletal muscle development with deregulated expression of myoregulatory transcription factors. Endocrinology 144:5138-5144. doi:10.1210/en.2003-0502

Flohr, J. R., M. D. Tokach, S. S. Dritz, J. M. DeRouchey, R. D. Goodband, J. L. Nelssen, and J. R. Bergstrom. 2014a. An evaluation of the effects of added vitamin $\mathrm{D}_{3}$ in maternal diets on sow and pig performance. J. Anim. Sci. 92:594-603. doi:10.2527/ jas.2013-6792

Flohr, J. R., M. D. Tokach, S. S. Dritz, J. M. DeRouchey, R. D. Goodband, J. L. Nelssen, S. C. Henry, L. M. Tokach, M. L. Potter, J. P. Goff, N. J. Koszewski, R. L. Horst, E. L. Hansen, and E. D. Fruge. 2014b. Effects of supplemental vitamin $\mathrm{D}_{3}$ on serum 25-hydroxycholecalciferol and growth of preweaning and nursery pigs. J. Anim. Sci. 92:152-163. doi:10.2527/jas.2013-6630

Flohr, J. R., J. C. Woodworth, J. R. Bergstrom, M. D. Tokach, S. S. Dritz, R. D. Goodband, and J. M. DeRouchey. 2016. Evaluating the impact of maternal vitamin D supplementation: I. Sow performance, serum vitamin metabolites, and neonatal muscle characteristics. J. Anim. Sci. 2016.94. doi:10.2527/jas2016-0409

Haddad, J. G., Jr., V. Boisseau, and L. V. Avioli. 1971. Placental transfer of vitamin $\mathrm{D}_{3}$ and 25-hydroxycholecalciferol in the rat. J. Lab. Clin. Med. 77:908-915.

Hines, E. A., J. D. Coffey, C. W. Starkey, T. K. Chung, and J. D. Starkey. 2013. Improvement of maternal vitamin D status with 25-hydroxycholecalciferol positively impacts porcine fetal skeletal muscle development and myoblast activity. J. Anim. Sci. 91:4116-4122. doi:10.2527/jas.2013-6565
Johnson, J. A., J. P. Grande, P. C. Roche, and R. Kumar. 1996. Ontogeny of the 1,25-dihydroxyvitamin $\mathrm{D}_{3}$ receptor in fetal rat bone. J. Bone Miner. Res. 11:56-61. doi:10.1002/jbmr.5650110109

Lauridsen, C., U. Halekoh, T. Larsen, and S. K. Jensen. 2010. Reproductive performance and bone status markers of gilts and lactating sows supplemented with two different forms of vitamin D. J. Anim. Sci. 88:202-213. doi:10.2527/jas.2009-1976

Mahan, D. C., and J. L. Vallet. 1997. Vitamin and mineral transfer during fetal development and the early postnatal period in pigs. J. Anim. Sci. 75:2731-2738. doi:10.2527/1997.75102731x

Musser, R. E., D. L. Davis, S. S. Dritz, M. D. Tokach, J. L. Nelssen, J. E. Minton, and R. D. Goodband. 2004. Conceptus and maternal responses to increased feed intake during early gestation in pigs. J. Anim. Sci. 82:3154-3161. doi:10.2527/2004.82113154x

NRC. 1988. Nutrient requirements of swine. 9th rev. ed. Natl. Acad. Press, Washington, DC.

NRC. 1998. Nutrient requirements of swine. 10th rev. ed. Natl. Acad. Press, Washington, DC.

NRC. 2012. Nutrient requirements of swine. 11th rev. ed. Natl. Acad. Press, Washington, DC.

Pluske, J. R., and G. Z. Dong. 1998. Factors influencing the utilization of colostrum and milk. In: M. W. A. Verstegen, P. J. Moughan, and J. W. Schrama, editors, The lactating sow. Wageningen Pers, Wageningen, The Netherlands. p. 45-70.

Priego Capote, F., J. R. Jimenez, J. M. Granados, and M. D. de Castro. 2007. Identification and determination of fat-soluble vitamins and metabolites in human serum by liquid chromatography/triple quadrupole mass spectrometry with multiple reaction monitoring. Rapid Commun. Mass Spectrom. 21(11):1745-1754. doi: $10.1002 / \mathrm{rcm} .3014$

Rortvedt, L. A., and T. D. Crenshaw. 2012. Expression of kyphosis in young pigs is induced by a reduction of supplemental vitamin $\mathrm{D}$ in maternal diets and vitamin $\mathrm{D}, \mathrm{Ca}$, and $\mathrm{P}$ concentrations in nursery diets. J. Anim. Sci. 90:4905-4915. doi:10.2527/jas.2012-5173

Schadt, H. S., R. Gössl, N. Seibel, and C. P. Aebischer. 2012. Quantification of vitamin $\mathrm{D}_{3}$ in feed, food, and pharmaceuticals using high-performance liquid chromatography/tandem mass spectrometry. J. AOAC Int. 95:1487-1494. doi:10.5740/jaoacint.11-512

Wahlstrom, R. C., and D. E. Stolte. 1958. The effect of supplemental vitamin $\mathrm{D}$ in rations for pigs fed in the absence of direct sunlight. J. Anim. Sci. 17:699-705. doi:10.2527/jas1958.173699x

Weber, G. M., A.-K. M. Witschi, C. Wenk, and H. Martens. 2014. Triennial Growth Symposium-Effects of dietary 25-hydroxycholecalciferol and cholecalciferol on blood vitamin D and mineral status, bone turnover, milk composition, and reproductive performance of sows. J. Anim. Sci. 92:899-909. doi:10.2527/ jas.2013-7209

Witschi, A.-K. M., A. Liesegang, S. Gebert, G. M. Weber, and C. Wenk. 2011. Effect of source and quantity of dietary vitamin D in maternal and creep diets on bone metabolism and growth in piglets. J. Anim. Sci. 89:1844-1852. doi:10.2527/jas.2010-3787 